\title{
SEAWOMIR KARP
}

ORCID: 0000-0002-6822-4831

\section{KARPIOWIE Z KARPOWICZ NA PODLASIU W OSTATNIEJ ĆWIERCI XVIII W. ZMIERZCH TRZYSTULETNIEJ HISTORII}

DOI: $10.15290 /$ sp.2021.29.04

Abstrakt. W artykule przedstawiono postać Antoniego Karpia (ok. 1747 - przed 12 III 1791) posesjonata dóbr Karpowicze na Podlasiu. Zarysowano także sylwetki kolejnych właścicieli tego majątku.

Słowa kluczowe: Karpiowie, Karpowicze, województwo podlaskie w XVIII w.

Abstract. The article presents the figure of Antoni Karp (ca. 1747 - ante 12.03.1791) the owner of the Karpowicze estate in the Podlasie Province in the $18^{\text {th }}$ century. The profiles of successive owners of this property were also outlined.

Key words: Karp family, Karpowicze estate, Podlaskie Voivodeship in the $18^{\text {th }}$ century

10 stycznia 1770 r. właścicielem majątku Karpowicze ${ }^{1}$ na Podlasiu został Antoni Karp h. własnego, najstarszy syn Stanisława Kazimierza i Racheli z Wolskich $^{2}$ Karpiów, koniuszych słonimskich. Urodził się on ok. 1747 r. Wiemy, że ojciec, oddalając pozostałe potomstwo, scedował mu także połowę dóbr Pierzchowicze w powiecie słonimskim ${ }^{3}$. Ogółem jednak scheda nie przedstawiała się zbyt imponująco, zwłaszcza że do spłaty pozostała jeszcze czwórka rodzeństwa (Józef, Dominik Wincenty i dwie nieznane nam z imion siostry).

1 Pierwotnie Brzozowa (i chociaż nazwa Karpowicze pojawia się w I poł. XVII w., starej używano jeszcze w 1676 r). Administracyjnie majętność leżała w powiecie brańskim ziemi bielskiej woj. podlaskiego.

2 Córka Michała Placyda i Racheli z Siemiradzkich Wolskich h. Półkozic, skarbników nowogródzkich. Vide: Archiwum Narodowe w Krakowie [dalej: ANKr.], Zbiór Zygmunta Glogera [tzw. Kapicjana] [dalej: ZZG], sygn. ZZG 41, s. 293.

3 Nacyânalny histaryčny archiu Belarusi [dalej: NGAB], f. 1755, inw. 1, nr 71, k. 132, 136. 28 stycznia (listopada) 1770 r. aktykowano do ksiąg grodzkich grodzieńskich, a 22 grudnia tegoż roku oblatowano w księgach starościńskich goniądzkich. 
W 1773 r. Antoni jako miejscowy dziedzic i kolator dofinansował kwotą 58 zł budowę nowego kościoła w Karpowiczach ${ }^{4}$. Z kolei 20 kwietnia 1775 r. razem z Franciszkiem Kobylińskim, podstolim słonimskim został pozwany do sądu ziemskiego słonimskiego z instancji Adama Chmary, instygatora WKL i Józefa Niesiołowskiego, wojewody nowogródzkiego na wniosek Leona Wołczackiego, exaktora pogłównego województwa nowogródzkiego. Formalnie sprawa dotyczyła Joachima Chreptowicza podkanclerzego WKL i wójta Nowogródka oraz tamtejszych burmistrzów Jakuba Pizelego i Michała Kamińskiego. Prawdopodobnie chodziło tu o szkody wyrządzone Żydom kahału nowogródzkiego: Abramowi Morduchowiczowi, Ickowi Micerowiczowi i Gierszonowiczowi. W następstwie tego woźny powiatowy zagarnął depozyt finansowy Antoniego ulokowany u Kobylińskiego w Wysocku w powiecie słonimskim ${ }^{5}$. Niestety, nie znamy jego wysokości. Natomiast 18 maja tego roku w Lipsku Murowanym w powiecie grodzieńskim woźny Teodor Kulikowski w imieniu Antoniego, Józefa i Dominika Karpiów, koniuszyców słonimskich wręczył pozew do Trybunału Głównego WKL kadencji ruskiej Anieli (Angeli) z Zaleskich Jundziłłowej, marszałkowej grodzieńskiej oraz jej dzieciom Franciszkowi, Piotrowi ${ }^{6}$, Barbarze, Konstancji i Annie. Ponieważ rozprawa ta nie przyniosła konkretnych rozwiązań, strony ponownie spotkały się na wokandzie 19 września $1776 \mathrm{r}^{7}$

4 Inwentarz sporządzony w 1820 r. podaje następujący opis: „Dach świątyni pokryty gontami, nad nim wznosi się kopuła. W dzwonnicy znajdują się dzwonki, natomiast duża sygnaturka znajduje się na kościele. Wnętrze kościoła wzbogacają trzy ołtarze. W ołtarzu głównym widniał wizerunek Najświętszej Maryi Panny Krasnoborskiej. W jednym z ołtarzy bocznych znajdował się obraz patrona tego kościoła św. Mikołaja, natomiast w drugim ołtarzu wizerunek św. Antoniego. Ołtarze te są już zbyt stare...wszystkie walące się i na nic nie zdatne bez żadnych ozdób...kościół drewniany w ziemię wlazły okorzuchowania potrzebny”. Z kolei w 1829 r. odnotowano: „między temi ołtarzami sklep z cegły fundatorów dawniej Karpiów, w którym się ich ciała chowały, na śrzodku kościoła, do którego drzwi z kamienia ciosanego, z herbem Karpiów wykutym. Ani w sklepie, ani w kościele ciała się nie chowają; nad sklepem na balku Pan Jezus czyli Krucyfiks". W 1865 r. władze rosyjskie w ramach represji popowstaniowych zamknęły kościół, a resztki wyposażenia przekazano do kościoła w pobliskiej Suchowoli, w tym obraz na drewnie Biczowanie Pana Jezusa u słupa kamiennego (na odwrocie napis: Karpowicze 1610 rok). Dawne grunty kościelne wraz z budynkami przejęła w 1866 r. Izba Dóbr Państwowych. Ostatecznie świątynię rozebrano, przeznaczając pozyskany materiał na cerkiew w Knyszynie. W 1989 r. na pamiątkę w miejscu, gdzie dawniej stał kościól, mieszkańcy Karpowicz posadowili murowaną kaplicę. Vide: J. Maroszek, Karpowicze - dzieje dworu, „Białostocczyzna” 1, 1995, s. 32-33.

5 NGAB, f. 1785, inw. 1, nr 54, k. 208-208v, k. 209-209v. Pozew przekazał Michał Wołk-Łaniewski, woźny nowogródzki.

6 Jako jedyny z rodzeństwa przebywał wówczas w Grodnie, pozostali wraz z matką rezydowali w Lipsku Murowanym.

7 Lietuvos valstybes istorijos archyvas, Vilnius [dalej: LVIA], SA 14805, k. 1484-1484v, 1496-1496v. Wezwanie Jundziłłom wręczył Antoni Szczerbiński, woźny grodzieński 14 września 1776 r. 
Następnie proces toczono 1 czerwca 1779 r. ${ }^{8}$ przed sądem trybunalskim kadencji grodzieńskiej. Wówczas braci Karpiów reprezentował Ignacy Zajączkowski, komornik województwa wileńskiego, a adwersarzami byli Piotr, Franciszek, Barbara, Konstancja i Anna Jundziłłowie, marszałkowiczowie grodzieńscy. Gra toczyła się o dużą stawkę, tj. spłatę z Lipska Murowanego, Hołynki i Narewki (Grodzisk, Mikłaszewo, wieś i dwór Siemianówka) po Janie Karpiu, wojskim grodzieńskim i Brzostowicy Murowanej (Brzostowiczany, Dołbienki, Koleśniki, Kordziki, Kowale, Ogrodniki alias Pod[ch]mielniki, Podbohonniki, Piennica $^{10}$ i Golnie) po Krzysztofie Ubaldzie, podkomorzycu ziemi bielskiej. W obu przypadkach Antoni wraz z braćmi ubiegał się o rekompensatę jako potomek Franciszka Karpia stryjecznego brata i bratanka zmarłych posesjonatów ${ }^{11}$. Co ciekawe, 27 listopada 1775 r. w ziemstwie grodzieńskim Piotr Jundziłł procesował się z Anielą z Zaleskich Jundziłłową, marszałkową grodzieńską i pozostałym potomstwem, tj. Franciszkiem, Barbarą, Konstancją oraz Anną o spadek po Karpiach, Łazowych i Połubińskich ${ }^{12}$.

Nieco wcześniej, tj. 14 czerwca 1775 r. Antoni Karp, koniuszyc słonimski sprzedał za 30000 zł połowę Pierzchowicz Ludwikowi Pancerzyńskiemu, miecznikowi mozyrskiemu ${ }^{13}$. W jej skład wchodziła część, która niegdyś przypadała stryjecznej siostrze ich ojca Stanisława Kazimierza, Rozalii z Karpiów primo voto Ludwikowej Czechowiczowej secundo voto Stanisławowej Marcinowej Niedźwieckiej ${ }^{14}$ oraz udział drugiej z sióstr Anny z Karpiów Franciszkowej

8 Skarga z 2 maja $1779 \mathrm{r}$.

9 Szerzej na ten temat: Jan Emanuel Karp (ok. 1706-1737), wojski grodzieński. Nota biograficzna, „Studia Podlaskie”, 28, 2020, s. 77-95.

10 W 1690 r. Krzysztof Ubald Karp z Brzostowicy Murowanej opłacił abiuratę z 30 dymów, natomiast z folwarku Golnie 10 dymów. Ten ostatni był wtedy zastawiony Bispingom. Podobnie z zastawionych Kordzików i Podbohonników opłacono podatek z 10 dymów. Vide: Metryka Litewska. Rejestry podymnego Wielkiego Księstwa Litewskiego. Województwo trockie 1690 r., oprac. H. Lulewicz, Warszawa 2000, s. 88. Wszystkie te majętności wchodziły w skład Brzostowicy Murowanej i razem obejmowały co najmniej 50 dymów. O randze tych dóbr świadczy też istnienie „pałacu murowanego" już w II poł. XVII w.

11 LVIA, SA 160, k. 11-12v. Dnia 4 maja w Grodnie Jundziłłowie otrzymali wezwanie od Macieja Cydzika, woźnego powiatowego, a $31 \mathrm{tm}$. Ignacy Piotrowin Janiszewski, pisarz i woźny trybunalski aktykował do ksiąg Trybunału Głównego WKL.

12 LVIA, SA 14805, k. 1467-1468v.

13 Dokument przyznał 23 czerwca tr. w ziemstwie słonimskim. Tym samym zakończył się ponadstuletni okres familijnego posesjonowania $w$ tym powiecie.

14 Prawa do $1 / 4$ części Pierzchowicz Stanisław Kazimierz Karp przejął 28 października 1760 r. Dokument aktykowano następnego dnia w magdeburgii żyrowickiej, a jednym ze świadków był Franciszek Antoni Białk, regent grodzki i ziemski wołkowyski. Przy czym wcześniej Rozalia zrzekła się swojej cząstki na brata Mikołaja Karpia, oboźnego słonimskiego. Vide: NGAB, f. 1755, inw. 1, nr 71, k. $129 \mathrm{v}$. 
Siemiradzkiej, rotmistrzowej województwa nowogródzkiego. Ta ostatnia wraz z Antonim potwierdziła transakcję 22 czerwca w magdeburgii żyrowickiej, a następnego dnia (23 VI) w ziemstwie słonimskim ${ }^{15}$. Natomiast 20 września 1775 r w Karpowiczach Antoni Karp otrzymał plenipotencję od Władysława Wołk-Łaniewskiego, starosty żebrowskiego na zajazd majątku Białaszewo ${ }^{16}$ $\mathrm{w}$ powiecie wiskim, będącego wówczas $\mathrm{w}$ posesji pana Klimaszewskiego. Wiemy, że Wołk-Łaniewski posiadał zgodę królewską na objęcie tych dóbr zgodnie $\mathrm{z}$ prawem kaduka ${ }^{17}$. Z późniejszych akt sądowych dowiadujemy się, że żaden $\mathrm{z}$ okolicznych szlachciców nie chciał przystać na ofertę starosty i dopiero przynaglony prośbami Karp uległ namowom dalekiego powinowatego ${ }^{18}$. Poza tym Antoni mieszkał niedaleko od Klimaszewskiego i zapewne też liczył na godziwą gratyfikację finansową po pomyślnym załatwieniu sprawy. Początkowo chciał on „dobrą przyjaźnią nakłonić do kombinacji [Klimaszewskiego], a że i tej, i innych nie usłuchał jegomości raczył [siłą] wyprosić" ${ }^{19}$. W rezultacie Antoni Karp uwikłał się w długoletni spór sądowy. Oprócz niego w procesie uczestniczyli także Adalbert Cybulski, Ignacy i Barbara Jabłonowscy oraz nieznany nam z imienia Kurzeniecki. Wymienia ich dekret ferowany 4 listopada 1782 r. w Goniądzu. Następnie za przyczyną adwersarza Kazimierza Płońskiego proces ten trafił do Trybunału lubelskiego ${ }^{20}$, ale jego zakończenia nie znamy.

Jeszcze przed 31 grudnia 1775 r. w wyniku obrażeń po napadzie Antoniego Józefa Ostrowskiego, cześnika bydgoskiego i pułkownika chorągwi lekkiej buławy wielkiej koronnej na majątek Karpowicze zmarł ojciec Antoniego, Stanisław Kazimierz Karp, koniuszy słonimski. W związku z tym młody dziedzic 15 stycznia 1776 r. wniósł do grodu grodzieńskiego skargę na prowodyra napaści oraz 30 najbrutalniejszych uczestników „różnej kondycji”. Karp w pozwie pisał:

15 NGAB, f. 1755, inw. 1, nr 71, k. 132, 136, 138v. W ten sposób Ludwik Pancerzyński dysponował już całymi Pierzchowiczami, mając połowę na własność a drugiej będąc zastawnikiem. 2 stycznia 1778 r. woźny Jakub Wróblewski intromitował Pancerzyńskiego w Pierzchowicze. Nie jest jasne, dlaczego 13 października tego roku odbyło się w tej sprawie posiedzenie sądu ziemskiego słonimskiego. Wiemy natomiast, że wypis z ksiąg ziemskich słonimskich wydano 28 stycznia $1778 \mathrm{r}$.

17 Otrzymał je w 1767 r. po teściu płk. Zagrzewskim. Vide: A. Boniecki, Herbarz polski, t. XV, Warszawa 1912, s. 172.

18 Pradziad Antoniego Chryzostom Karp (1650-1714), podkomorzyc ziemi bielskiej był szwagrem Gerwazego Wołk-Łaniewskiego, wojskiego mozyrskiego.

19 NGAB, f. 1755, inw. 1, nr 65, k. 893-893v. Świadkami plenipotencji byli: Franciszek Wołk-Łaniewski, cześnik nowogródzki i Wiktor Szumkowski.

20 LVIA, SA 14804, k. 723-724v. Ekstrakt dekretu z Goniądza do ksiąg ziemskich rosieńskich podał Antoni Woyna w dniu 2 września 1796 r. 
[płk. Ostrowski] nic nie zważając na prawa ludzkie, i boskie, i lekceważąc bezpieczeństwo sąsiedzkie domów i osób szlacheckich, nie mając żadnego powodu, jedynie tylko sposobem przemocy lub za wziętym jakimś pretekstem i używszy ich do ucisku sąsiadów, mając powierzone sobie dowództwo wyżej rzeczonego oddziału dla ochrony dobra publicznego, z przydzielonymi sobie wspólnikami i towarzyszącymi osobami, liczbą sto przenoszącymi, do najazdu dóbr wsi Karpowicze i ucisku niegdy[ś] wielmożnego ojca, [którego] pochwyciwszy wybiegającego na krzyk bitych i wypędzanych ludzi ze swojego dworu...między sobą zatrzymali, zatrzymanego to kijami, to batami, to pięściami, to różnym rodzajem oręża razem z broniącą go...najdroższą matką [Rachelą] ogromnie zbili, wychłostali, zbitego na ziemię powalili, powalonego końmi tratowali i potrącali.

Po kilku tygodniach stary Karp zmarł. Na domiar złego agresorzy uprowadzili ośmiu poddanych do Dolistowa, które wtedy dzierżawił płk. Antoni Józef Ostrowski, cześnik bydgoski. Utrata części siły roboczej z niewielkiego majątku jeszcze bardziej nadwątliła pozycję gospodarczą Antoniego Karpia. Uprowadzeni chłopi „przez kilka tygodni w ścisłym więzieniu domowym [w Dolistowie], pracą codzienną męcząc [byli] przetrzymywani”. Ponadto płk. Ostrowski zagarnął spory kawał areału Karpowicz, który miał być wydzierżawiony Annie z Narzymskich primo voto Kazimierzowej Kuczyńskiej secundo voto Piotrowej Zaleskiej, podkomorzynie nurskiej. Oprócz tego cześnik mając od dzierżawcy boguszewskiego ${ }^{21}$ dwie zakażone krowy po pierwszej nieudanej próbie umieszczenia ich w majątku Grodzisk kazał przygnać je do Karpowicz ${ }^{22}$. W konsekwencji od chorych krów rozpleniła się zaraza i Karpiom padło ponad 150 sztuk bydła, a w tym wiele dorodnych wołów ${ }^{23}$.

Pogarszająca się sytuacja finansowa rodziny Karpiów negatywnie odbiła się także na ich wzajemnych relacjach. 11 maja $1776 \mathrm{r}$. Antoni razem z braćmi został pozwany do sądu przez matkę. Rachela zażądała od synów wypłacenia

21 Użycie „małej litery” jednoznacznie wskazuje na arendatora ze wsi Bogusze, pomimo że w bliskiej okolicy żyło wielu przedstawicieli drobnoszlacheckich rodzin Boguszewskich pieczętujących się h. Ostoja i h. Juńczyk.

22 Tamtejszy ekonom szlachcic Łazewski „ze strachu przed zarażeniem bydła” odmówił ich przyjęcia.

23 NGAB, f. 1711, inw. 1, nr 60, k. 294-296. Wypis skargi z ksiąg grodzkich starościńskich goniądzkich sporządził w Grodnie Szumkowski. Zapewne należał on do rodziny, która trzy dekady później nabyła dobra Karpowicze. 
kwoty $26000 \mathrm{zt}^{24}$. Żądanie to, choć zasadne, ${ }^{25}$ znacznie przekraczało możliwości oskarżonych. Już wtedy młody Karp cierpiał na chroniczny brak gotówki i często zapożyczał się u różnych kredytorów, m. in. 17 listopada 1777 r. pożyczył 54 zł od Siwickiego, ekonoma zabielskiego ${ }^{26}$. Poza tym Antoni miał wówczas szereg innych poważnych kłopotów. Pod koniec 1782 r. aresztowano go i osadzono w więzieniu w Białymstoku. Co było tego przyczyną, nie wiemy, ale problemy te skrupulatnie wykorzystał Dzierżek ${ }^{27}$, sędzia grodzki goniądzki, z którym koniuszyc już wcześniej popadł w konflikt. Zresztą dla ówczesnych nie było to tajemnicą, że „u [Dzierżka] nietrudno jest niegodziwy dekret napisać”. Obawy były tym większe, że faktycznie odgrażał się on „oddać [Karpia] na wieczne więzienie do Kamieńca" ${ }^{28}$. Prawdopodobnie miało to związek z dekretem zapadłym 30 czerwca 1783 r. w grodzie goniądzkim, w którym zaocznie skazano Antoniego i Rachelę Karpiów na zapłacenie „grzywien i sum”. Niestety nie znamy ich wielkości ani szczegółów procesu. Co gorsza, w tym czasie dobra Karpowicze uległy dalszemu rozdrobnieniu ${ }^{29}$. Coraz więcej różnych „pretendentów” i wierzycieli domagało się zwrotu pożyczek ${ }^{30}$. Szczęśliwie dla Karpiów sądy działy opieszale. Na następnym procesie $\mathrm{w}$ grodzie goniądzkim, $\mathrm{tj}$. $\mathrm{w}$ poniedziałek 28 czerwca 1784 r. sprawę ponownie odłożono do rozpatrzenia przez Trybunał Koronny lubelski ${ }^{31}$. Z kolei 11 września 1784 r. Antoni wspólnie z matką i braćmi Józefem i Dominikiem Wincentym oraz „dalszym potomstwem” toczył spór przed sądem ziemskim słonimskim z Franciszkiem Kobylińskim, sędzią ziemskim słonimskim o Pierzchowicze. Już 9 września zaprotokołowano zeznanie woźnego Jakuba Wróblewskiego dotyczące relacji Antoniego Jana

24 W proces zamieszane było także małżeństwo Franciszków Kobylińskich, podstolich słonimskich.

253 lipca 1746 r. w Światyczach Stanisław Kazimierz Karp, strażnik słonimski zapisał jej posag na Karpowiczach. Vide: LVIA, SA 157, k. 374-376v.

26 LVIA, SA 14804, k. 721.

27 Zapewne Maciej Dzierżek, sędzia grodzki goniądzki.

28 Archiwum Główne Akt Dawnych [dalej: AGAD], Archiwum Roskie. Korespondencja, pudło LXIII, nr 63, s. 8 .

29 Mianem dziedziców Karpowicz zostali określeni także: Sczanieccy; Umińscy; Kazimierz, subdelegat grodzki brański i Franciszek, burgrabia grodzki wiski, Płońscy; Maciej Komorowski; Abdon Cywiński; Ludwik Pry[s]zmont; Michał, Jan, Grzegorz i Wincenty, rotmistrz piński, Jabłonowscy oraz Maciej Boraczewski. Do jakiś sum z Karpowicz pretendowali również nieznani nam z imion Wołk i Tarant (sic!).

30 Natomiast do wierzycieli należeli „szlachetni” Piotr Sakowski, Adam Cieślik (sic!), Paweł Bało „mieszkańcy Królestwa Prus”, których na procesie 28 czerwca 1784 r. przed sądem grodzkim goniądzkim reprezentował pełnomocnik Krzysztof Rutkowski, kapitan wojsk Królestwa Pruskiego. Z nieznanych nam względów w sprawę uwikłani byli też Ignacy Kurzeniecki, chorąży piński i Kazimierz Sulewski.

31 LVIA, SA 14804, k. 727-727v. 
Kobylińskiego, wojskiego i podstarościego oraz Wiktora Połubińskiego, stolnika i sędziego grodzkiego słonimskiego w procesie z Karpiami. Odwoływano się wówczas do dekretu Trybunału litewskiego z 12 czerwca $1782 \mathrm{r}^{32}$ Natomiast 22 listopada w Iwankowiczach woźny Wróblewski wręczył pozew Franciszkowi Kobylińskiemu, sędziemu ziemskiemu słonimskiemu z powództwa Michała Wincentego i Petroneli ze Święcickich Wołłowiczów, pisarzy skarbowych WKL i starostów niemonoyckich. W sporze tym brała udział także cała rodzina Karpiów, a dokumenty procesowe odnotowują Antoniego 23 listopada $1784 \mathrm{r}^{33}$

W owym czasie proboszcz Stefan Trzeciak opisując dzierżoną parafię karpowicką wspomina: „młyn pusty na rzece Brzozowa do J[aśnie] P[anów] Karpiów należący ${ }^{34}$...kościół parafialny J[aśnie] P[ani] Karpiowej, na wschód wiosnowy względem kościoła dolistowskiego mila jedna wielka...nie zawsze przeprawić się można, na zachód słońca letniego od kościoła chodorowskiego pół mili” ${ }^{35}$. Co ciekawe, pomimo niesnasek rodzinnych jeszcze w $1784 \mathrm{r}$. mieszkała tam matka Rachela Karpiowa, koniuszyna słonimska.

Natomiast 31 maja 1787 r. Antoni wraz z braćmi Józefem i Dominikiem skarżył Franciszka Jundziłła, podkomorzego grodzieńskiego dziedzica Witkowszczyzny w powiecie grodzieńskim i Jana Krzywkowskiego, dworzanina skarbowego $\mathrm{WKL}^{36}$. Możemy się domyślać, że powodem sporu były kwestie materialne, a jak wiemy, Karpiowie coraz bardziej wpadali w pętlę zadłużeń. Majątek był niewielki i miał słabe gleby, stąd nie przynosił odpowiednich dochodów dla licznej rodziny obciążonej dużymi zobowiązaniami finansowymi. W 1781 r. wieś liczyła 230 osób $^{37}$. Natomiast Taryffa Dymów i Podatku Podymnego $z$ Dóbr Ziemskich $w$ Woiewodztwie Podlaskim Ziemi Bielskiej leżacych z nowej Lustracyi Roku 1790 przez Prześwietne Komissye Porzadkowo-Cywilno-woyskowe czynioney ułożona podaje w folwarku Karpowicze 21 dymów klasy drugiej i sumę podymnego wyliczoną na $155 \mathrm{zł} \mathrm{(1} \mathrm{rata} 77$ złotych 15 groszy $)^{38}$.

32 NGAB, f. 1785, inw. 1, nr 56, k. 811-811v.

33 Ibidem, k. 1034-1034v.

34 J. Maroszek, op. cit., s. 34.

35 Rękopiśmienne opisy parafii litewskich z 1784 r. Dekanat Knyszyński i Dekanat Augustowski, oprac. W. Wernerowa, Warszawa 1996, s. 39, 166. Z kolei na s. 195 podano opis położenia kościoła, wsi („leży wzdłuż rzeki Brzozowej...czasami wylewom podległej, czyniąc złą, przykrą i niebezpieczną przeprawę”) oraz „borku” („mało sośniny, więcej chojny mający”) i lasu („olchowy, trochę jesionowy, łozy dużo, długi na ćwierć mili”) w Karpowiczach.

36 LVIA, SA 14805, k. 1471-1471v.

37 S. Ostrowski, Karpowicze - dzieje parafii, „Białostocczyzna” 1, 1995, s. 22-27.

38 Taryffa Dymów i Podatku Podymnego z Dóbr Ziemskich w Woiewodztwie Podlaskim Ziemi Bielskiej leżących z nowej Lustracyi Roku 1790 przez Prześwietne Komissye Porządkowo-Cywilno-woyskowe czynioney ułożona, s. 94 . 
Z kolei inne źródło w tymże roku oblicza wieś Karpowicze na 31 dymów ${ }^{39}$. Natomiast z plebanii w Karpowiczach wyliczono 8 dymów drugiej klasy i 40 zł (1 rata $20 \mathrm{zl})$ podatku ${ }^{40}$.

Antoni Karp, koniuszyc słonimski zmarł bezpotomnie przed 12 marca $1791 \mathrm{r}^{41}$ Miał wtedy ok. 44 lat. Zapewne pochowano go w starym mauzoleum rodzinnym w Karpowiczach ${ }^{42}$. Jego bezpośredni kolejni przodkowie byli tam grzebani od ok. 1547 r., tj. począwszy od Karpia Jesypowicza, sędziego hospodarskiego ${ }^{43}$. Antoni Karp należał do dziesiątego udokumentowanego pokolenia rodziny, a dziewiątego dziedziczącego tę majętność.

W tym czasie, tj. przed 12 marca 1791 r., także bezżennie zmarł najmłodszy syn koniuszych słonimskich Dominik Wincenty Karp ${ }^{44}$. Trudno dociec, kiedy dokładnie się urodził, ale z pewnością nastąpiło to nie wcześniej niż w $1753 \mathrm{r}$. W każdym razie 18 maja 1775 r. był pełnoletni. Następnie wzmiankowano go w pozwie matki przeciwko synom z 11 maja 1776 r. oraz 12 czerwca 1782 r. waktach Trybunału Koronnego w procesie z Franciszkiem Kobylińskim, sędzią ziemskim słonimskim ${ }^{45}$ a także w pozwach z 21 października i 22 listopada 1784 r. Michała Wincentego i Petroneli ze Święcickich Wołłowiczów. Natomiast 2 września tegoż roku razem z matką i bratem Józefem wniósł skargę na Piotra marszałka, Franciszka podkomorzego, urzędników grodzieńskich, Konstancję i Annę Jundziłłów właścicieli Lipska Murowanego w powiecie grodzieńskim. Jeszcze 31 maja 1787 r. Dominik Wincenty Karp skarżył wraz z braćmi Franciszka Jundziłła, podkomorzego grodzieńskiego $\mathrm{z}$ Witkowszczyzny $\mathrm{w}$ powiecie grodzieńskim oraz Jana Krzywkowskiego, dworzanina skarbowego WKL. Później odnajdujemy go dopiero 18 marca 1790 r. w Szwekszniach w powiecie pojurskim na Żmudzi podczas chrztu Antoniego syna Szymona i Reginy z Macelewiczów Lachowiczów szlachciców z Szołpian. Dominik Wincenty Karp wraz z Ludwiką Kunicką asystował tam rodzicom chrzestnym Nikodemowi Kownackiemu, kanonikowi żmudzkiemu, proboszczowi w Szwekszniach i Juliannie Bucewiczównie ${ }^{46}$. Nigdy

39 Atlas gwar wschodniosłowiańskich Białostocczyzny, t. 1 (1980), nr 15, s. 37.

40 Taryffa Dymów..., s. 296.

41 LVIA, SA 13807, k. 159v, k. 165; SA 13808, k. 338v.

42 Ponieważ plebania w Karpowiczach spłonęła w nocy z 26 na 27 sierpnia 1834 r., nie zachowały się metryki przedstawicieli rodziny Karpiów. Vide: Национальный исторический архив Беларуси в 2. Гродно, f. 98, inw. 1, teka 1149, k. 1.

43 S. Karp, Los szesnastowiecznego egzulanta briańskiego na przykładzie Karpia Jesypowicza (ur. ok. 1480 zm. przed 10 X 1547), „Studia Podlaskie”, 23, 2015, s. 7-30.

44 LVIA, SA 13807, k. 165.

45 Ibidem, SA 166, k. 491v.

46 Ibidem, f. 1665, Ap. 1, nr 4, k. 104. 
nie posiadał własności ziemskiej i nie możemy zaliczyć go do grona posesjonatów. Najpewniej tułał się po braterskich skromnych wiktach w Karpowiczach i Szołpianach-Borejkianach.

Nie jest jasne, dlaczego 3 maja 1793 r. Dominik Wincenty Karp, koniuszyc słonimski jako żyjący był wymieniony wspólnie z Felicjanem Karpiem, sędzią ziemskim żmudzkim w pozwie przeciwko Piotrowi Jundziłłowi, generał adiutantowi JKM właścicielowi dóbr Karolin ${ }^{47}$. W dwóch pozostałych pozwach złożonych tego samego dnia, tj. przeciwko Janowi Stryjeńskiemu, szefowi lejbgwardii konnej litewskiej, a także versus Franciszkowi i Teresie Jundziłłom, podkomorzym powiatu grodzieńskiego i konsyliarzom Rady Nieustającej ${ }^{48}$ również jako skarżącego do sądu ziemiańskiego grodzieńskiego podano Dominika Wincentego Karpia ${ }^{49}$. Z pewnością możemy uznać to za błąd pisarza przygotowującego wezwania. Niewątpliwie korzystał on ze starych akt procesowych i pomylił nieżyjącego już Dominika Wincentego z ostatnim z braci Józefem. Kolejne potwierdzenie bezpotomnego zgonu Dominika Wincentego pochodzi z 4 lutego 1793 r., ${ }^{50}$ a zatem nie mógł on w maju tego roku pozywać kogokolwiek do sądu. Natomiast nie mamy pewności, gdzie złożono jego ciało. Do pochówku mogło dojść zarówno w rodzinnych Karpowiczach na Podlasiu, jak i w Szwekszniach będących ośrodkiem parafialnym Szołpian-Borejkian majątku brata Józefa, gdzie, jak widzieliśmy, Dominik Wincenty jakiś czas przebywał. Nie można także wykluczyć, że nie mając stałego oparcia materialnego, zaciągnął się on do wojska i zginął między 18 marca 1790 r. a 12 marca 1791 r. na polu bitewnym.

Wiemy, że koniuszycowie mieli jeszcze dwie siostry, ale niestety nie znamy ich imion. Starszą wymieniono 11 maja 1776 r. w pozwie matki o 26000 zł. Już wtedy była żoną któregoś z Massalskich ${ }^{51}$. Wzmiankowano ją później jeszcze krótko po 25 lutym a następnie 12 czerwca $1782 \mathrm{r}^{52}$ Po raz ostatni spotykamy ją w źródłach 21 stycznia 1799 r., kiedy to brat Józef Karp zobowiązał się ostatecznie wypłacić jej należną sumę z dóbr ojcowskich ${ }^{53}$. W tym dokumencie odnotowano również drugą z sióstr. Zobowiązania wobec niej także przejął na siebie Józef ${ }^{54}$.

47 NGAB, f. 1755, inw. 1, nr 77, k. 1206v. Dokument wręczył Józef Zabłocki, woźny grodzieński, aktykowano 8 maja $1793 \mathrm{r}$.

48 NGAB, f. 1755, inw. 1, nr 78, k. 1207-1207v. Pozew wręczono w Grodnie.

49 Ibidem, k. 1206. Do skargi przyłączyli się też: Ignacy, rotmistrz żmudzki i Franciszek Maurycy (błędnie zapisany jako Michał), Karpiowie.

50 LVIA, SA 13807, k. 159v; SA 13808, k. 338v.

51 NGAB, f. 1737, inw. 1, nr 51, k. 257v. Niekiedy tak zapisywano Mossalskich.

52 LVIA, SA 166, k. 491.

53 Ibidem, SA 14573, k. 804v.

54 Ibidem, k. 804v. 
Więcej informacji o tych Karpiównach nie mamy. Ich matka Rachela żyła jeszcze 21 stycznia $1799 \mathrm{r}^{55}$

Natomiast Józef Karp ${ }^{56}$, koniuszyc słonimski, jako jedyny z żyjących braci 12 marca 1791 r. w ziemstwie kowieńskim skwitował z odbioru kwoty 30000 zł dalekiego krewnego z tzw. linii rykijowskiej Felicjana Karpia ${ }^{57}$, sędziego ziemskiego repartycji rosieńskiej i komisarza cywilno-wojskowego żmudzkiego. Pieniądze były zapisane na Karpowiczach i Pierzchowiczach ${ }^{58}$. Jednocześnie bez oprocentowania pożyczył mu na 3 lata (do 23 kwietnia 1794 r.) sumę $20400 \mathrm{zt}^{59}$. Ponadto scedował prawa kolacyjne do kościoła w Karpowiczach ${ }^{60}$. Tym samym Felicjan Karp został nowym właścicielem majątku, płacąc zaledwie 600 zł gotówki. Przy czym już w 1784 r. w aktach goniądzkich razem z braćmi Maurycym Franciszkiem i Ignacym figurował jako dziedzic Karpowicz $^{61}$. Co ciekawe, tak samo wtedy tytułowano Teodora Siwickiego, syna Michała $^{62}$.

Felicjan Karp, nabywając majętność karpowicką, wziął na siebie także wszystkie ciążące na niej wierzytelności. Widzimy, że dość szybko zaczął je spłacać. Znamienne, że w pierwszej kolejności najbardziej kosztowną i zarazem najważniejszą. Już 17 marca 1792 r. w grodzie brańskim ${ }^{63}$ uregulował zobowiązania wobec spadkobierców po bezpotomnie zmarłym płk. Antonim

55 Ibidem. Jej losy autor przedstawia w artykule Stanisław Kazimierz Karp (1726-1775), koniuszy słonimski. Nota biograficzna, mps.

56 Dalsze dzieje koniuszyca Józefa Karpia zawarte są w tekście Karpiowie z Szolpian w powiecie pojurskim. Przyczynek do dziejów osiemnastowiecznej migracji szlachty podlaskiej na Żmudź, mps.

57 Syn Józefa i Barbary z Nagurskich Karpiów, ciwunów ejragolskich. W 1780 r. ożenił się z Karoliną hr. Platerówną, starościanką giegobrodzką i subocką. Wspólnego przodka z Józefem mieli w drugiej połowie XVI w. Był nim Iwan Karp (ok. 1535-1591), starosta nowodworski.

58 LVIA, SA 13807, k. 158-161v; ibidem, SA 14803, k. 493-493v.

59 Ibidem, SA 13807, k. 164-164v.

60 Ibidem, k. 165-165v. Świadkowali: Adam Onufry, regent ziemski kowieński i grodzki wiłkomirski oraz Marcin, skarbnik oszmiański i vice regent ziemski kowieński, kniaziowie Świrscy, a także Wincenty Domeyko, budowniczyc kowieński.

61 Poza tym żmudzcy Karpiowie wystąpili o schedę w powiecie słonimskim. 1 lipca 1778 r. w tamtejszym ziemstwie Barbara z Nagurskich Karpiowa, ciwunowa ejragolska wraz z synami Maurycym Franciszkiem, Felicjanem i Ignacym procesowała się o nią z Bogumiłą z Wolbeków Wereszczakową, chorążyną brzeską i jej wnukiem Ludwikiem Pancerzyńskim, miecznikiem mozyrskim. Vide: NGAB, f. 1755, inw. 1, nr 71, k. 129, 131, 132. Ignacy Jankowski, rotmistrz smoleński 2 czerwca 1786 r. podał ekstrakt dekretu do akt ziemskich grodzieńskich. Kolejny wyrok w tej sprawie zapadł na posiedzeniu w dniu 21 października tego roku, ale i on nie zakończył sporu między nimi a następna rozprawa odbyła się w sądzie trybunalskim 24 lipca $1789 \mathrm{r}$.

62 ANKr., ZZG 41, s. 356.

6328 czerwca 1796 r. w księgach ziemskich ziemi bielskiej goniądzkich oblatował Borowski, regent ziemi bielskiej, a 28 lipca 1796 r. podał do ksiąg ziemskich rosieńskich. 
Józefie Ostrowskim, cześniku bydgoskim ${ }^{64}$. A trzeba przyznać, że grono to było bardzo liczne. Należeli do niego w wielkości połowy długu: Dionizy miecznik kowalski, Antoni Konstanty i Józef, kanonik łucki, Umińscy; Stanisław i Konstancja z Umińskich Białochowscy, stolnikowie radziejowscy; Franciszek i Kazimiera z Umińskich Świerczyńscy, podstolowie brzescy; Marianna Ignacowa Gnatowska; sukcesorzy Marianny z Ostrowskich Wawrzyńcowej Umińskiej oraz Anny z Ostrowskich primo voto Aleksandrowej Orzelskiej secundo voto Józefowej Bartołdowej. Natomiast do drugiej połowy wierzytelności pretendowali: Franciszek Sczaniecki, łowczy kaliski; Paweł Wargowski, Tadeusz Wodecki i Kazimierz Żółtowski mężowie Salomei, Krystyny, Justyny ze Sczanieckich oraz następcy po Pawle i Teresie z Ostrowskich Sczanieckich. Wyasygnowana przez sędziego Karpia kwota wynosiła 36970 zł, a odebrał ją ich plenipotent Tadeusz Szymon Bończa-Skarżyński, skarbnik łomżyński. W skład sumy dłużnej wchodziły zobowiązania dawnych dziedziców Karpowicz. Były to zaciągnięte 27 czerwca 1772 r. u płk. Ostrowskiemu w Dolistowie $3600 \mathrm{zt}^{65}$, 28 maja 1763 r. u Jakuba Wolskiego, podczaszego orszańskiego 4000 zł, które płk. Ostrowski nabył wlewkiem 30 października 1774 r. oraz 120 zł z 15 kwietnia 1776 r. i 20000 zł pożyczone u niego 18 stycznia 1778 r. w Dolistowie ${ }^{66}$. Poza tym cześnik bydgoski przejął szereg innych drobniejszych długów Karpiów, jak choćby u Płońskiego na 250 zł, Karwowskiego na 2000 zł, czy u Pijarów konwentu szczuczyńskiego na 4000 zł. Wszystkie obwarowane były na Karpowiczach. $Z$ akt procesowych czerpiemy informację, że Felicjan już 23 lutego 1775 r. w Pocztowie otrzymał od braci Maurycego Franciszka i Ignacego plenipotencję, by odzyskać Karpowicze. Podpisał się też pod nią Józef Karp, koniuszyc słonimski ${ }^{67}$.

30 kwietnia 1792 r. przed procesem sądowym o następne obligi Felicjan w imieniu matki i braci wyznaczył na plenipotentów Tadeusza Szymona Bończę-Skarżyńskiego, skarbnika łomżyńskiego i nieznanego nam z imienia Dederkę. Obaj mecenasi mieli reprezentować Karpiów w Trybunale Koronnym lubelskim w sporze z Kazimierzem Płońskim, sędzią ziemi bielskiej, Maciejem Komorowskim, rotmistrzem grodzieńskim i Ludwikiem Pryszmontem ${ }^{68}$. Po kilku latach

64 Po jego śmierci żona Barbara z Jabłonowskich poślubiła Michała Ostrowskiego.

65 Przyznane 3 lipca 1772 r. w grodzie goniądzkim.

6616 czerwca 1778 r. oblatowano w księgach ziemskich tykocińskich.

67 LVIA, SA 14804, k. 731-734v. 27 lutego tr. aktykowano do ksiąg grodzkich kowieńskich.

68 Ibidem, SA 14798, k. 239-239v. Pieczętowali: Wawrzyniec Pikturna i Adam Narkiewicz, porucznik powiatowy ks. żmudzkiego. Natomiast 5 maja 1792 r. do ksiąg ziemiańskich powiatu rosieńskiego aktykował Felicjan Karp. 
sporu, tj. 21 stycznia 1796 r. $^{69}$ Felicjan wyznaczył nowego plenipotenta Antoniego Jaworowskiego, regenta bielskiego, by reprezentował go przed sądem w Szczuczynie (sic! $)^{70}$. Najpewniej Karp miał już dosyć tych utarczek prawnych i 10 czerwca tr. w Goniądzu pospłacał kwity dłużne, które adwersarze przejęli prawem wlewkowym. Były to stare długi Mikołaja Karpia, oboźnego słonimskiego zaciągnięte u Jana Jabłonowskiego w kwocie 34 czerwonych złotych oraz u Jerzego i Katarzyny z Hrehorowiczów Houwaltów, skarbników starodubowskich $^{71}$ z 15 marca 1757 r. na 70 tynfów i z 3 stycznia 1759 r. na 400 tynfów. Czwarty oblig w wysokości 290 tynfów wystawiła Katarzynie Houwaltowej 20 lipca 1761 r. w Karpowiczach żona oboźnego Justyna z Wolskich Karpiowa późniejsza Józefowa Sienińska, cześnikowa wołkowyska. Ogółem Felicjan Karp wypłacił 1089 zł i $10 \mathrm{gr}^{72}$. W międzyczasie, tj. 28 lutego 1795 r. odkupił za 24000 zł od brata Ignacego, sędziego ziemskiego i rotmistrza szawelskiego trzecią część Karpowicz w województwie podlaskim, Pierzchowicz w powiecie słonimskim i Pocztowa w powiecie wilkijskim. Płatność uregulował „złotem holenderskim rachując 1 czerwony złoty po 18 zł[otych] polskich"73.

Niewątpliwie nowy dziedzic rządził twardą ręką w Karpowiczach. Wskazują na to przykłady zbiegostwa poddanych, m. in. 17 czerwca 1796 r. w liście z Karpowicz Felicjan zwrócił się do komisarza dóbr białostockich Hryniewieckiego, aby ten nakazał „gromadzie dolistowskiej” wydać „bez mitręgi” zbiega o nazwisku Sobota. Sędzia Karp pisał: „[chłop ten] dziedziczny uszedł z Karpowicz z siostrą i parą wołów a przez czas gospodarowania swojego we wsi mojej [Karpowiczach] wiele dworowi w zbożu i zapomodze winnym został" ${ }^{\prime 4}$. W $1797 \mathrm{r}$. ponownie wszyscy trzej bracia Felicjan, sędzia ziemski rosieński, Maurycy Franciszek, starosta jodajcki i Ignacy, rotmistrz i były sędzia ziemski szawelski, Karpiowie nazwani zostali dziedzicami w Karpowiczach ${ }^{75} .27$ września tr. dwaj

69 Kazimierz Płoński nie pełnił już wówczas urzędu sędziego.

70 LVIA, SA 14804, k. 21-21v. Karpiowi świadkowali: Mateusz Minmont, pisarz ziemski i Dionizy Paszkiewicz, regent ziemski, urzędnicy żmudzcy. Dokument do ksiąg ziemskich rosieńskich podał Felicjan Karp 12 stycznia 1796 r.

71 S. Uruski, A.A. Kosiński, A. Włodarski, Rodzina. Herbarz szlachty polskiej, t. V, Warszawa 1908, s. 203 wymienia Jerzego Houwalta jako skarbnika inflanckiego.

72 LVIA, SA 14804, k. 737-737v. 2 września 1796 r. Antoni Woyna podał do akt ziemskich rosieńskich. Natomiast ekstrakt cesji z kwitem w ziemstwie goniądzkim ziemi bielskiej złożył Adam Jakowicz, regent ziemski żmudzki.

73 Ibidem, SA 14806, k. 490-491v. Pieczętarzami byli: Franciszek (Frank) z Rymwida Mickiewicz, komornik żmudzki i Antoni Urniaż. Dokument ten 10 lutego 1798 r. podał do akt ziemskich rosieńskich Józef Romaszkiewicz, rotmistrz inflancki.

74 AGAD, Archiwum Roskie. Korespondencja, pudło XXI, nr 120.

75 ANKr., ZZG 41, s. 386. 
ostatni (Maurycy Franciszek i Ignacy) odstąpili Felicjanowi za 80000 zł swoje części dóbr Karpowicze ${ }^{76}$. Wielkość transakcji wskazuje, że definitywnie ustąpili oni także z Pocztowa w powiecie wilkijskim i Pierzchowicz w słonimskim. Wydaje się jednak, że ze strony Ignacego było to wyłącznie potwierdzenie wcześniejszej transakcji (1795). Dziwi też, że dopiero 21 stycznia 1799 r. w grodzie rosieńskim Felicjan umocował Andrzeja Mietelskiego, komornika ziemi łomżyńskiej do akceptacji tego kontraktu ${ }^{77}$.

5 czerwca 1800 r. Felicjan Karp ponownie wszczął spór sądowy z Franciszkiem i Teresą Jundziłłami ${ }^{78}$. Prawdopodobnie bez większego efektu. Był ostatnim z rodziny właścicielem Karpowicz. Spotykamy go tam 3 maja 1807 r., ${ }^{79}$ a także w 1809 r. Zmarł w sędziwym wieku po 29 listopada 1840 r. Z powodu sporej odległości od jego ojczystych dóbr na Żmudzi ${ }^{80}$, które znalazły się wówczas pod zaborem rosyjskim, sprawy zarządu majątkiem Karpowicze znajdującym się pod zaborem pruskim powierzał wynajętym administratorom. W 1804 r. był nim Mietelski, choć 30 stycznia tegoż roku w skardze włościan ze wsi Horodnianka, Podhorodnianka, uroczyska Zakał oraz wsi Ciemne, Dwugły i Poddwugły $\mathrm{z}$ klucza ostrowickiego parafii suchowolskiej powiatu dąbrowskiego $\mathrm{w}$ amtcie ${ }^{81}$ grodzieńskim złożonej do Kamery chłopi nazwali go dziedzicem ${ }^{82}$. W owym czasie próbował zagarnąć część gruntów, na których od dawna ci włościanie gospodarzyli ${ }^{83}$.

W tym miejscu warto choćby krótko wspomnieć o następnych właścicielach Karpowicz. Byli nimi Szumkowscy h. Abdank. Najprawdopodobniej dobra przejęli krótko po $1812 \mathrm{r}^{84}$ Niedługo potem wybudowali tam nową siedzibę. Był

76 LVIA, SA 13809, k. 1715-1716v; ibidem, SA 14573, k. 808v; ANKr., ZZG 41, s. 386. Świadkami byli: Marcin, regent ziemski kowieński i Onufry, pisarzewicz ziemski kowieński, Świrscy oraz Michał Talatowicz, mostowniczyc trocki. Dokument aktykowano do ksiąg ziemskich kowieńskich.

77 LVIA, SA 14573, k. 808-808v. Pieczętowali: Józef Romaszkiewicz, rotmistrz inflancki i Antoni Ostrowski. 21 stycznia 1799 r. zapisano do akt grodzkich rosieńskich. Zapewne to właśnie Andrzej Mietelski 18 października 1797 r. był odnotowany jako plenipotent księcia Michała Radziwiłła. Vide: Archiwum Państwowe w Białymstoku, Sumariusz dokumentów Kamery Wojny i Domen w Białymstoku 1796-1807 [dalej: APB, Sumariusz], sygn. 1956, k. 9.

78 NGAB, f. 1711, inw. 1, nr 77, k. 468.

79 A. Meysztowicz, Karpiowie herbu własnego, Wilno 1906, s. 74.

80 Posiadał m. in. Pocztów w powiecie wilkijskim, Raczkuny w powiecie wilkiskim, dzierżawę wsi Powicie i lenność Łopolaty (Rymkowszczyzna, Rymgajłowszczyzna) w powiecie kowieńskim.

81 Amt - jednostka podziału administracyjnego.

82 Z pewnością określenie to odzwierciedla jedynie „stronę praktyczną”, bowiem jeszcze wtedy właścicielem Karpowicz był zamieszkały na Żmudzi sędzia Felicjan Karp.

83 APB, Sumariusz, sygn. 1180, s. 8-10.

84 Ustalenie dokładnej daty sprzedaży majątku Karpowicze przez Felicjana Karpia nie jest możliwe ze względu na brak akt sprzed $1820 \mathrm{r}$. 
to parterowy dwór modrzewiowy z czterokolumnowym portykiem od frontu ${ }^{85}$. W 1820 r. parafia, a tym samym wieś i majątek Karpowicze, to 234 mieszkańców. Po powstaniu styczniowym w wyniku carskich represji ówczesny dziedzic Alojzy Szumkowski został skazany na zsyłkę i konfiskatę majątku. W rezultacie Karpowicze przeznaczono do przymusowej sprzedaży ${ }^{86}$. Jednak Szumkowskim udało się ocalić połowę areału, ponieważ dobra formalnie należały także do drugiego brata Antoniego. Dlatego mimo wcześniejszej konfirmacji ferowanego wyroku przez generał-gubernatora Michaiła Mikołajewicza Murawjowa „Wieszatiela” (1796-1866) ${ }^{87}$, dopiero 12 kwietnia 1872 r. zatwierdzono wydzielenie na rzecz skarbu rosyjskiego $1 \frac{1}{2}$ tego majątku. Nadano jej nazwę Karpiniec. $\mathrm{Na}$ mocy zezwolenia carskiego z dnia 18 marca $1874 \mathrm{r}$. na sprzedaż poddanej konfiskacie połowy dóbr Karpowicze, grunty Karpińca kupił Mikołaj Rubcow, naczelnik kancelarii generał-gubernatora. 13 kwietnia 1874 r. sporządzono akt zbycia rzeczonej części majątku obejmującej 337 dziesięcin ziemi. Notabene warunki zakupu były bardzo zachęcające. Zgodnie z instrukcją z 23 lipca 1865 r. nabywca miał uiścić sumę 3500 rubli, płatną ratami po 175 rubli rocznie w ciągu 20 lat. 16 kwietnia 1874 r. Rubcow został wprowadzony w posiadanie Karpińca $^{88}$. Z kolei pozostawiona przy rodzinie Szumkowskich druga część Karpowicz w połowie XIX w. miała pozostałe $337 \mathrm{dz}$. ziemi ${ }^{89}$. Pomimo znacznego uszczuplenia dóbr Szumkowscy utrzymali się tam do 14 lipca 1899 r. Tego dnia sprzedali folwark Zofii Krejbichowej ${ }^{90}$. Nowi właściciele należeli do sfery kupieckiej, mieli pochodzenie czeskie i wywodzili się z miasta Kamień.

85 Wygląd siedziby dworskiej dokumentuje pocztówka z okresu międzywojennego. Za jej udostępnienie składam serdeczne podziękowanie Panu Januszowi Zarembie-Władyczańskiemu, kolekcjonerowi z Białegostoku.

86 Rodzina Szumkowskich oprócz Karpińca straciła także Żuchowo (140dz. ziemi) w powiecie sokólskim. Vide: J. Iwaszkiewicz, Wykaz dóbr ziemskich skonfiskowanych przez rządy zaborcze w latach 1773-1867, Warszawa 1929, s. 46, 48.

87 Urząd sprawował od maja 1863 do kwietnia $1865 \mathrm{r}$.

886 października 1923 r. syn Alojzego Szumkowskiego Stefan wystąpił do Sądu Okręgowego w Białymstoku przeciwko spadkobiercom Mikołaja Rubcowa o zwrot Karpińca. Jego ostatni właściciele Mikołaj jun. i Zofia, zamężna Borzienko, tj. dzieci Mikołaja sen. Rubcowa zaginęli w Rosji podczas rewolucji październikowej. A zatem całość Karpińca przypadła synom drugiej córki Mikołaja sen. Rubcowa Lubowi, tj. Sergiuszowi i Arseniuszowi Kułakowskim. Sąd Okręgowy wyrokiem z dnia 5-19 grudnia 1924 r., unieważnił zaskarżony akt sprzedaży z 13 kwietnia 1874 r. i uznał Stefana Szumkowskiego za prawowitego właściciela połowy majątku Karpowicze, istniejącej jako odrębny majątek Karpiniec oraz nakazał odebrać tenże majątek według stanu z $1874 \mathrm{r}$. Wyrok ten utrzymał w mocy Sąd Apelacyjny w Warszawie (13-27 października - 10 listopada 1925 r.) a także Sąd Najwyższy (12 maja 1928 r.) (nr sprawy I C 592/26). Vide: https://sip.lex.pl > orzeczenia-sadow > i-c-592-26-orzeczenie (dostęp: 20.05.2021).

891 dz. tzw. skarbowa $=1,09252$ ha.

90 J. Maroszek, op. cit., s. 35. 
W okresie międzywojennym w Karpowiczach gospodarzył Antoni Krejbich ${ }^{91}$, a grunty liczyły już tylko 228 ha. ${ }^{92}$ Był on ostatnim właścicielem tego majątku. Po II wojnie światowej osiadł w Anglii, gdzie zmarł w 1994 r. Krótko po działaniach wojennych pozostałości budynków dworskich rozebrano, a drzewa z założenia parkowo-ogrodowego wycięto. W następstwie olbrzymiej dewastacji i rozbiórek zniszczone dawne siedlisko dworskie (XVI w.) w Karpowiczach zaorano. Do dzisiaj z założenia dworsko-parkowo-ogrodowego przetrwał zaledwie jeden kamienny budynek gospodarczy oraz dwa słupy bramne.

$\mathrm{Na}$ przestrzeni wieków właścicielami Brzozowej-Karpowicz byli: Maciej Moniuszko, wójt okolicznych ziem do 23 lutego 1505 r.; bojar Mordas Bołoticz (zm. tuż po 7 czerwca 1519 r.) z żoną Pelagią Hryńkówną od 23 lutego 1505 do krótko po 7 czerwca 1519 r.; następnie od ok. połowy 1520 r. przedstawiciele rodziny Karpiów: Karp Jesypowicz (ok. 1480 - zm. przed 10 października 1547 r.), egzulant briański i sędzia hospodarski, żonaty z Pelagią Hryńkówną primo voto Hryniową z Grusa secundo voto Mordasową Bołoticzową; Iwan Karp (ok. 1535-1591), starosta nowodworski; Józef (ok. 1567-1637), marszałek wołkowyski; Jan (1604-1644) podstoli podlaski; od 1649 r. Józef (1630-1687), podkomorzy ziemi bielskiej; Stanisław Antoni (ok. 1679-1719), podkomorzyc ziemi bielskiej; Jan (ok. 1706-1737), wojski grodzieński; od 1747 r. Mikołaj (ok. 17221759), oboźny słonimski; od 19 lutego 1767 r. Stanisław Kazimierz (1726-1775), koniuszy słonimski; od 10 stycznia 1770 r. Antoni (ok. 1747 - zm. przed 12 marca 1791), koniuszyc słonimski; po nim krótko Józef (ok. 1750 - zm. przed 10 kwietnia 1810), koniuszyc słonimski; a od 12 marca 1791 r. do ok. 1812 r. Felicjan (ok. 1754 - zm. po 29 listopada 1840), sędzia ziemski rosieński; Szumkowscy od ok. 1812 do 14 czerwca 1899 r. (ale od 12 kwietnia 1872 r. tylko połowy majątku); po nich od 12 kwietnia 1899 r. do 1944 r. Krejbichowie; a drugiej części zwanej Karpińcem Rubcowowie od 13 kwietnia 1874 r. do 5-19 grudnia 1924 r. i od tego momentu Stefan Szumkowski.

Jak widzimy, najdłużej dobrami Karpowicze (Brzozowa) na Podlasiu władała rodzina Karpiów h. własnego (ok. 292 lata) zachowując własność w jednej linii tzw. podlasko-białoruskiej przez 271 lat, następnie Szumkowscy h. Abdank gospodarując tam 87 lat, chociaż przez ostatnie 27 lat tylko na połowie majątku. Równocześnie rosyjska rodzina Rubcowów 51 lat także na 1⁄2 majętności. Ostatni właściciele majątku Krejbichowie (na połowie dawnych Karpowicz) przez 45 lat.

91 W maju 1919 r. jako członek rady powiatowej został wybrany z powiatu sokólskiego na Sejm Ustawodawczy Rzeczpospolitej Polskiej.

92 J. Maroszek, op. cit., s. 35. 
Podczas dzierżenia dóbr przez rodzinę Karpiów wystąpiły dwie przerwy w ciągłości posiadania. Pierwsza od 13 kwietnia 1737 r. do 8 maja 1742 r., bowiem utrzymała się tam na dożywociu Katarzyna $\mathrm{z}$ Kotowiczów primo voto Janowa Karpiowa, wojszczyna grodzieńska secundo voto Franciszkowa Michałowa Wereszczakowa, skarbnikowa brzeska, a po jej śmierci do 1747 r. majątek objęli Konstancja z Jundziłłów primo voto Stanisławowa Antoniowa Karpiowa secundo voto Samuelowa Łazowa, kasztelanowa mścisławska oraz Tadeusz i Franciszka z Łazowych Jundziłłowie, podkomorzowie grodzieńscy (10 lat). Druga przerwa nastąpiła od 1760 r. do 18 lutego 1767 r., kiedy to mieszkała tam również mając dożywocie (7 lat) Justyna z Półkoziców Wolskich, primo voto Mikołajowa Karpiowa, oboźnina słonimska secundo voto Józefowa Sienińska, cześnikowa wołkowyska.

A zatem ciągłość bytności Karpiów w Karpowiczach na przestrzeni 292 lat została uszczuplona w sumie tylko o 17 lat.

\section{Bibliografia}

\section{Źródła archiwalne}

Archiwum Główne Akt Dawnych w Warszawie:

- Archiwum Roskie. Korespondencja, pudło XXI, nr 120; pudło LXIII, nr 63.

Archiwum Narodowe w Krakowie:

- Zbiór Zygmunta Glogera (tzw. Kapicjana), sygn. 41.

Archiwum Państwowe w Białymstoku:

- Sumariusz dokumentów Kamery Wojny i Domen w Białymstoku 1796-1807, sygn. 1180, 1956.

Lietuvos valstybes istorijos archyvas (Vilnius):

- SA 157, 160, 166, 13807, 13808, 14573, 14798, 14803, 14804, 14805, 14806, 13809.

- f. 1665, Ap. 1, nr 4.

Национальный исторический архив Беларуси в г. Гродно

- f. 98, inw. 1, teka 1149.

Nacional'nyj istoričeskij arhiv' Belarusi (Nacyânalny histaryčny archiu Belarusi, Мінск): - f. 1711, inw. 1, nr 60, nr 77; f. 1737, inw. 1, nr 51; f. 1755, inw. 1, nr 65, 71, 78; f. 1785, inw. 1, nr 54, 56. 


\section{Źródła drukowane}

Atlas gwar wschodniosłowiańskich Białostocczyzny, t. 1 (1980), nr 15.

Metryka Litewska. Rejestry podymnego Wielkiego Księstwa Litewskiego. Województwo trockie 1690 r., oprac. H. Lulewicz, Warszawa 2000.

Rękopiśmienne opisy parafii litewskich z 1784 roku. Dekanat Knyszyński i Dekanat Augustowski, oprac. W. Wernerowa, Warszawa 1996.

Taryffa Dymów i Podatku Podymnego z Dóbr Ziemskich w Woiewodztwie Podlaskim Ziemi Bielskiej leżacych z nowej Lustracyi Roku 1790 przez Prześwietne Komissye Porząkowo-Cywilno-woyskowe czynioney ułożona.

\section{Opracowania i artykuły}

Boniecki A., Herbarz polski, t. XV, Warszawa 1912.

Iwaszkiewicz J., Wykaz dóbr ziemskich skonfiskowanych przez rządy zaborcze w latach 1773-1867, Warszawa 1929.

Karp S., Jan Emanuel Karp (ok. 1706-1737), wojski grodzieński. Nota biograficzna, „Studia Podlaskie”, 28, 2020.

Karp S., Karpiowie z Szołpian w powiecie pojurskim. Przyczynek do dziejów osiemnastowiecznej migracji szlachty polskiej na Żmudź, mps.

Karp S., Los szesnastowiecznego egzulanta briańskiego na przykładzie Karpia Jesypowicza (ur. ok. 1480 - zm. przed 10 X 1547), „Studia Podlaskie”, 23, 2015.

Karp S., Stanisław Kazimierz Karp (1726-1775), koniuszy słonimski. Nota biograficzna, mps.

Maroszek J., Karpowicze - dzieje dworu, „Białostocczyzna” 1, 1995.

Meysztowicz A., Karpiowie herbu własnego, Wilno 1906.

Ostrowski S., Karpowicze - dzieje parafii, „Białostocczyzna” 1, 1995.

Uruski S., Kosiński A.A., Włodarski A., Rodzina. Herbarz szlachty polskiej, t. V, Warszawa 1908.

\section{Internet}

https://sip.lex.pl > orzeczenia-sadow > i-c-592-26-orzeczenie (dostęp: 20.05.2021). 


\title{
The Karp family from Karpowicze in Podlasie in the last quarter of the $18^{\text {th }}$ century. The twilight of three hundred years of history
}

\begin{abstract}
Summary
The purpose of this article is to present the figure of Antoni Karp. He inherited the Karpowicze estate in the Podlasie Province. He lived in the second half of the $18^{\text {th }}$ century. He died shortly before March 12, 1791. Probably Karp was buried in the church in Karpowicze. He was the representative of the ninth generation of the family in the Podlasie Province.
\end{abstract}

Sławomir Karp - mgr ekonomii, heraldyk, niezwiązany z żadnym ośrodkiem naukowym. Zainteresowania badawcze: genealogia i heraldyka kresowych rodzin Rzeczypospolitej Obojga Narodów. e-mail: skarp63@hotmail.com 